\title{
Effect of N, P, K and Mg fertilizers on some vegetative and generative parameters of a sweet cherry cultivar
}

\author{
Csihon, Á. ${ }^{1}$, Gonda, I. ${ }^{1}$, Orosz-Tóth, M. ${ }^{2}$, Kincses, S. ${ }^{2} \&$ Holb. I. J. ${ }^{1}$ \\ ${ }^{1}$ University of Debrecen, Faculty of the Agricultural and Food Sciences and Environmental Management, \\ Institute of Horticulture, 138. Böszörményi str., Debrecen, H-4032, Hungary, \\ ${ }^{2}$ University of Debrecen, Faculty of Agricultural and Food Sciences and Environmental Management, \\ Institute of Agricultural Chemistry and Soil Science, 138. Böszörményi str., Debrecen, H-4032, Hungary, \\ Author for correspondence: csihonadam@agr.unideb.hu
}

\begin{abstract}
Summary: This two-year-study was aimed to provide results on the effect of nitrogen, phosphorus, potassium and magnesium fertilizer treatments (control, NP, NPK, NPKMg) on vegetative and generative features of the sweet cherry cultivar 'Carmen'. Examinations were performed in an orchard planted in 2012 on Prunus mahaleb rootstock with spacing of $5 \times 2.5 \mathrm{~m}$. All treatments improved the vegetative features of the sweet cherry trees in both years of 2016 and 2017. Fertilizer treated trees increased trunk cross section area (TCSA) with 51.3-63.1\%, while control trees showed 48.3\% trunk growth increase. Yields of control trees were lower in both years $(5.9-7.2 \mathrm{~kg} / \mathrm{tree})$, than that of the fertilized trees $(7.8-11.3 \mathrm{~kg} / \mathrm{tree})$. Treatments also increased the phosphorus (16-22\%), magnesium (12-20\%) and potassium content (3.5-18\%) of the fruits compared to control treatments.
\end{abstract}

Csihon, Á., Gonda, I., Orosz-Tóth, M., Kincses, S., Holb. I. J. (2020): Effect of N, P, K and Mg fertilizers on some vegetative and generative parameters of a sweet cherry cultivar. International Journal of Horticultural Science 26: 27-30. https://doi.org/10.31421/IJHS/26/2020/8001

Key words: sweet cherry, nutrient management, fruit yield, fruit quality

\section{Introduction}

Sweet cherry (Prunus avium L.) is a fruit species with worldwide importance with a continuous production increase. In 2018, the world production reached 2.5 million tons (FAO, 2020). Despite the increasing production tendency, considerably less research studies were conducted for the sweet cherry than for other deciduous fruit crop such as apple and peach (Neilsen et al., 2017). In Hungary sweet cherry is a cultivated in 2800 hectares, as the annual production is about 15 000-18 000 tons per year (FAO, 2020). Based on the last decade sweet cherry belongs to the fruit crops with increased interest, thanks to the high demand of the fruits and favorable marketing trends (Csihon et al., 2017).

Sweet cherry grows one of the largest natural tree among fruit tree species. Researches all over the world focus on intensity growing by evaluating rootstocks, cultivars and canopies (Balmer \& Blanke, 2005; Matthew et al., 2005; Cantín et al., 2010; Vaszily \& Gonda, 2010; Csihon et al., 2018). Tree physiology management is oriented to reach high fruit yield and quality by producing a balance between the reproductive structures and vegetative growth (Predieri et al., 2003). In order to reach this, a unique nutrient requirement of the new cultivar and rootstock have to be assessed (Neilsen et al., 2017).

Increasing demands on quantitative and qualitative requirements can be reached with the use of appropriate nutrient supply practices, as nutrient management affect all tree management practices (Nagy, 2009). Plant nutrition influences significantly the fruiting capacity of fruit trees. Nutritional status of trees in the season is mainly determined by the nutrient supply practices and the actual fruit load as well as by other growing and climatic factors (Wilkinson, 1968; Quinlan, 1971; Sadowski, 1995). Nevertheless, according to Gonda (2008), nutrient management of orchards is the most controversial element of the production technology in Hungary, which is manifested in instinctive solutions.

Nutrient supply is highly dependent upon intensity of the production technology. If the intensity of production is higher, the production is more sensitive to favorable nutritional conditions compared to lower production intensity (Papp, 2003). The importance of nutrient supply greatly affects long-term profitability. No long-term experiments have been available in Hungarian research for the past decades. Therefore, neither the positive nor negative effects of nutrient supply could be detected effectively for the production parameters (Gonda, 2008). Therefore, it is essential to develop nutrient optimum levels for cultivars of each fruit species in order to optimize yields and fruit quality (Nagy, 2009).

This two-year-study was aimed to provide results on the effect of nitrogen, phosphorus, potassium and magnesium fertilizer treatments (control, NP, NPK, NPKMg) on vegetative and generative features of the sweet cherry cultivar 'Carmen'.

\section{Materials and methods}

\section{Experimental site}

The experiments were carried out at the Experimental Farm of University of Debrecen, in Pallag from the year of 2016. The 
major soil parameters of the orchard are listed in Table 1. Physical category of soil is light sandy loam, as the $\mathrm{pH}$ of soil is slightly alkaline ( $\mathrm{pH}$ 7.5-7.6). The humus content is between 1.2 and $1.6 \%$. The $\mathrm{NO}_{3-}+\mathrm{NO}_{2^{-}}-\mathrm{N}$ content of the soil is between $3.02-5.10 \mathrm{mg} / \mathrm{kg}$ depending on the depth, which is lower than the required optimal level $(8.0-10.0 \mathrm{mg} / \mathrm{kg})$. Potassium content can be considered high (301-351 mg/kg).

Table 1. Soil parameters of the experimental sweet cherry orchard (Debrecen-Pallag, 2016).

\begin{tabular}{|c|c|c|c|}
\hline & $0-20 \mathrm{~cm}$ & $20-40 \mathrm{~cm}$ & $40-60 \mathrm{~cm}$ \\
\hline Humus content (\%) & 1.6 & 1.5 & 1.2 \\
\hline "Arany" number of heaviness & 28 & 27 & 26 \\
\hline$p H$ & 7.6 & 7.6 & 7.5 \\
\hline $\mathrm{NO}_{3^{-}}+\mathrm{NO}_{2^{-}}-\mathrm{N}(\mathrm{mg} / \mathrm{kg})$ & 3.02 & 5.10 & 4.36 \\
\hline $\mathrm{AL}-\mathrm{P}_{2} \mathrm{O}_{5}(\mathrm{mg} / \mathrm{kg})$ & 146 & 95 & 83 \\
\hline$A L-K_{2} O(m g / k g)$ & 351 & 330 & 301 \\
\hline$A L-M g(\mathrm{mg} / \mathrm{kg})$ & 108 & 97 & 145 \\
\hline $\mathrm{CaCO}_{3}(\mathrm{~m} / \mathrm{m}) \%$ & 0.33 & 0.35 & 0.21 \\
\hline
\end{tabular}

The study was performed on sweet cherry cultivar 'Carmen'. Trees were drafted on Prunus mahaleb rootstock and were planted in 2012 with spacing of $5 \times 2.5 \mathrm{~m}$. Trees were trained to free spindle with the height of $3.5 \mathrm{~m}$. Each applied treatments of $\mathrm{N}$ (Calcium Ammonium Nitrate - 27\% N, 7\% CaO, 5\% MgO), $\mathrm{P}$ (Superphosphate - 18\% $\left.\mathrm{P}_{2} \mathrm{O}_{5}\right), \mathrm{K}\left(\mathrm{KCl}-60 \% \mathrm{~K}_{2} \mathrm{O}\right)$ and $\mathrm{Mg}$ ( $\mathrm{MgO}-25 \% \mathrm{MgO}, 20 \% \mathrm{~S}$ ) (Table 2) were used for 5 trees under similar tree conditions.

Table 2. Applied treatments and doses of N, P, K and Mg fertilizers in the experimental sweet cherry orchard.

\begin{tabular}{|l|c|c|c|c|}
\hline & $\begin{array}{c}\boldsymbol{N} \\
(\mathrm{kg} / \mathrm{ha})\end{array}$ & $\begin{array}{c}\mathrm{P}_{2} \mathrm{O}_{5} \\
(\mathrm{~kg} / \mathrm{ha})\end{array}$ & $\begin{array}{c}\mathrm{K}_{2} \mathrm{O} \\
(\mathrm{kg} / \mathrm{ha})\end{array}$ & $\begin{array}{c}\mathrm{MgO} \\
(\mathrm{kg} / \mathrm{ha} \boldsymbol{)}\end{array}$ \\
\hline Control & 0 & 0 & 0 & 0 \\
\hline $\boldsymbol{N}+\boldsymbol{P}$ & 60 & 80 & 0 & 0 \\
\hline $\boldsymbol{N}+\boldsymbol{P}+\boldsymbol{K}$ & 60 & 80 & 100 & 0 \\
\hline $\boldsymbol{N}+\boldsymbol{P}+\boldsymbol{K}+\mathbf{M g}$ & 60 & 80 & 100 & 30 \\
\hline
\end{tabular}

In the spring of 2016, fertilizers were applied together. Later phosphorus, potassium and magnesium fertilizers were applied in autumn, and nitrogen in spring. Fertilizers were incorporated to the soil with rotary hoe and rake at all time.

\section{Assessed parameters}

Disease incidence of cherry leaf spot was determined in the control plots at harvest as the percentage of disease and healthy. Trunk thickness, as the complex index of the vegetative accomplishment was determined in autumn, after leaf fall in each year and expressed in trunk cross sectional area (TCSA, $\left.\mathrm{cm}^{2}\right)$. Fruit yield per tree was measured $(\mathrm{kg} /$ tree) and calculated to trunk cross sectional area $\left(\mathrm{g} / \mathrm{cm}^{2}\right)$. Fruit size $(\mathrm{mm})$ was evaluated based on 20 fruits per tree (100 fruits per treatment). Fruit samples were used for inner value examinations (dry matter, $\mathrm{P}, \mathrm{K}, \mathrm{Mg}$ content). Statistics were performed by ANOVA at $\mathrm{P}=0.05$ level using LSD test.

\section{Results and discussion}

Disease incidence of cherry leaf spot was below 5\% at harvest in both years in 2016 and 2017 in the control fertilizer spot, ensuring that the treatment effect was not affected by the health status of the trees.

In 2015, before the beginning of the experiments trunk cross sectional area of the trees varied between 52.4 and $65.0 \mathrm{~cm}^{2}$. In 2016 measured trunk thickness was $61.0-76.8 \mathrm{~cm}^{2}$, which means 12.7-18.3\% increase during one vegetation period (Table 3). Differences become more obvious in $2017\left(79.4-106.0 \mathrm{~cm}^{2}\right)$, as TCSA growth was the lowest with control trees (25.3\%), while fertilized trees presented 30.2-38.0\% increment compared to the previous year. During two vegetation period treated trees achieved 51.3-63.1\% TCSA increase, while control trees showed $48.3 \%$ trunk growth. The largest increase was measured in NP treatment $(63.1 \%)$, followed by NPK treatment $(55.4 \%)$.

Table 3. Trunk cross sectional area (TCSA) (Debrecen - Pallag, 2015-2017).

\begin{tabular}{|l|c|c|c|c|c|c|}
\hline & $\begin{array}{c}\text { TCSA } \\
\mathbf{2 0 1 5} \\
\left(\mathbf{c m}^{2}\right)\end{array}$ & $\begin{array}{c}\text { TCSA } \\
\mathbf{2 0 1 6} \\
\left(\mathbf{c m}^{2}\right)\end{array}$ & $\begin{array}{c}\text { TCSA } \\
\mathbf{2 0 1 7} \\
\left(\mathbf{c m}^{2}\right)\end{array}$ & $\begin{array}{c}\text { Change } \\
\text { from 2015 } \\
\text { to 2016 } \\
(\boldsymbol{\%})\end{array}$ & $\begin{array}{c}\text { Change } \\
\text { from 2016 } \\
\text { to 2017 } \\
(\boldsymbol{\%})\end{array}$ & $\begin{array}{c}\text { Change } \\
\text { from 2015 } \\
\text { to 2017 } \\
(\boldsymbol{\%})\end{array}$ \\
\hline Control & 59.8 & 70.8 & 88.7 & 18.3 & 25.3 & 48.3 \\
\hline NP & 65.0 & 76.8 & 106.0 & 18.1 & 38.0 & 63.1 \\
\hline NPK & 63.7 & 71.8 & 99.1 & 12.7 & 38.0 & 55.4 \\
\hline NPKMg & 52.4 & 61.0 & 79.4 & 16.3 & 30.2 & 51.3 \\
\hline LSD5\% & - & 27.5 & 36.2 & - & - & - \\
\hline
\end{tabular}

Yields of control trees were lower in both years (5.9-7.2 $\mathrm{kg} /$ tree), than in the case of the fertilized trees (7.8-11.3 kg/tree) (Figure 1). In 2016, NP treatment showed the highest fruit amount $(11.3 \mathrm{~kg} /$ tree $)$, followed by NPK (9.5 kg/tree) and NPKMg treatment $(9.0 \mathrm{~kg} / \mathrm{tree})$. In 2017 differences among the fertilized trees were more balanced $(8.3-9.0 \mathrm{~kg} /$ tree $)$.

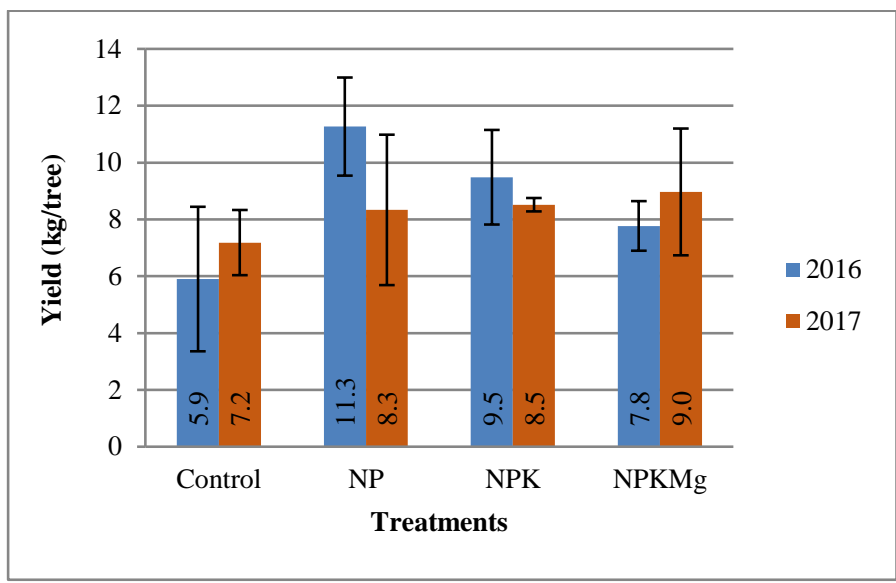

Figure 1. Harvested fruit amount sweet cherry cultivar 'Carmen' (Debrecen-Pallag, 2016-2017).

In 2016, crop load (fruit amount calculated to the trunk thickness) was higher with all treatments (Figure 2). Fertilized trees displayed $152-180 \mathrm{~g} / \mathrm{cm}^{2}$ values, as control treatment presented only $94 \mathrm{~g} / \mathrm{cm}^{2}$. In 2017 , crop load was lower, due to the unfavorable weather events in spring. The highest values were measured in NPKMg treatment $\left(115 \mathrm{~g} / \mathrm{cm}^{2}\right)$, followed by NPK treatment $\left(93 \mathrm{~g} / \mathrm{cm}^{2}\right)$. 


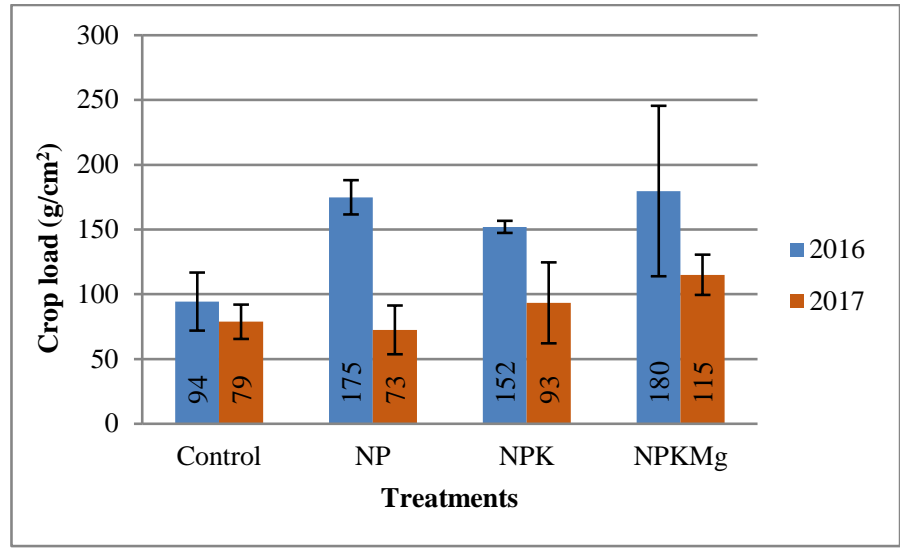

Figure 2. Crop load of sweet cherry cultivar 'Carmen' (Debrecen-Pallag, 2016-2017).

Cultivar 'Carmen' is one of the largest fruit-sized Hungarian sweet cherry cultivar. Comparing the two years, fruit diameter was larger in $2016(32.9-34.6 \mathrm{~mm})$ in all treatments despite the higher crop load values (Figure 3). In 2017, differences in fruit size was more balanced among the treatments $(31.4-32.7 \mathrm{~mm})$, the smallest diameter was recorded in control treatment.

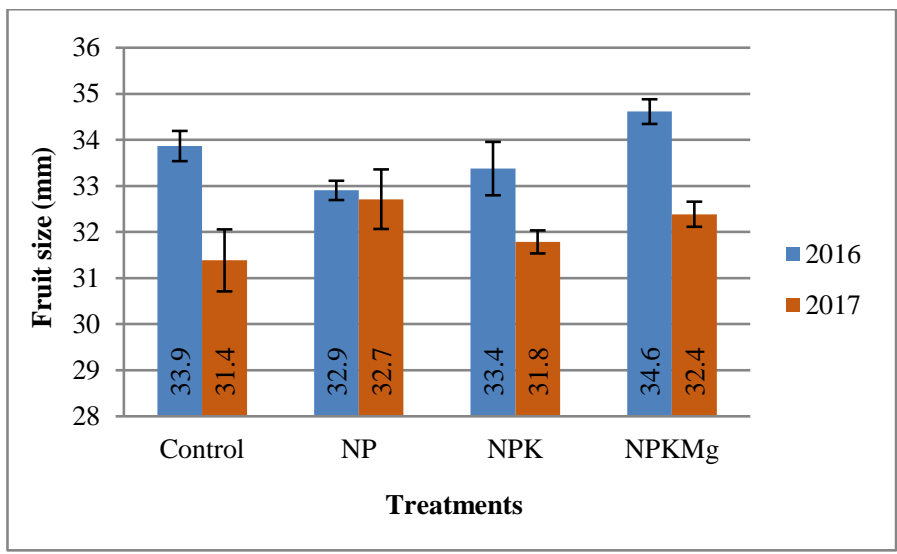

Figure 3. Fruit size sweet cherry cultivar 'Carmen' (Debrecen-Pallag, 2016-2017).

In both years, dry matter content was the highest with the control treatment (15.3-16.3 g/100g) (Figure 4). Measured values of the fertilized trees were 12.8-13.7 in 2016 and 15.115.4 in 2017. Accordingly, treatments decreased the dry matter content of the fruit, which can be related with the higher yields of the fertilized trees.

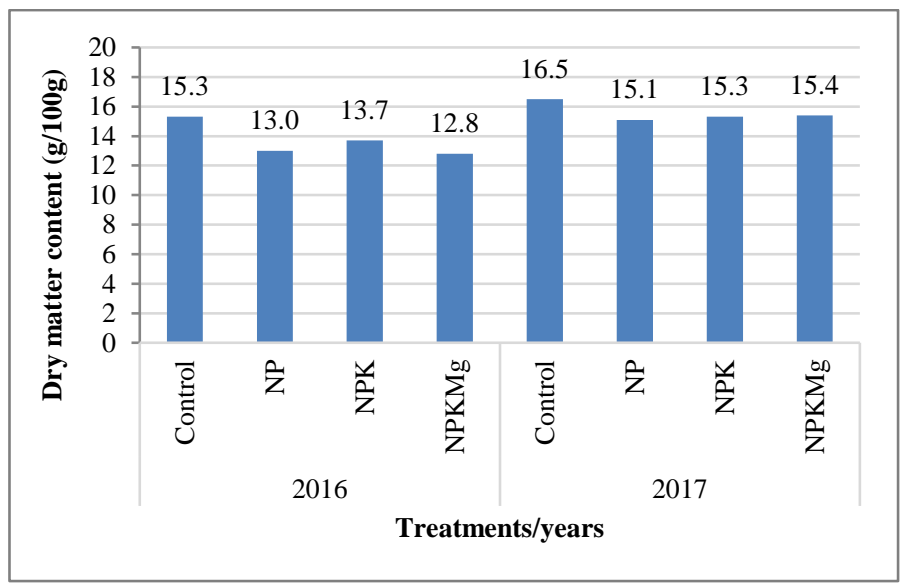

Figure 4. Dry matter content of the fruits (Debrecen-Pallag, 2016-2017).
Element content of the fruits is presented in Figure 5-6. In 2016 obvious tendency can not be seen, however treatments caused well visible changes in 2017. Phosphorus content of the fruits grew with $16-22 \%(115-121 \mathrm{mg} / \mathrm{kg})$ compared to the control $(99 \mathrm{mg} / \mathrm{kg})$. Magnesium content was higher with 12 $20 \%(55-59 \mathrm{mg} / \mathrm{kg})$ than in the untreated trees $(49 \mathrm{mg} / \mathrm{kg})$. Changes in potassium content were also more evident in 2017. Largest improvement was detected with NPKMg treatment $(18 \%)$.

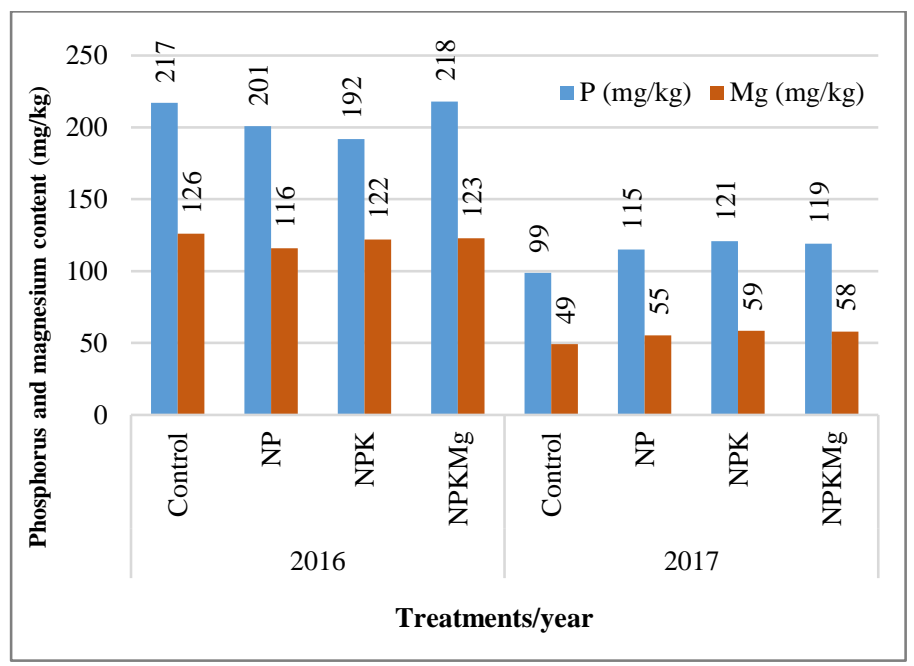

Figure 5. Phosphorus and magnesium content of the fruits (Debrecen-Pallag, 2016-2017).

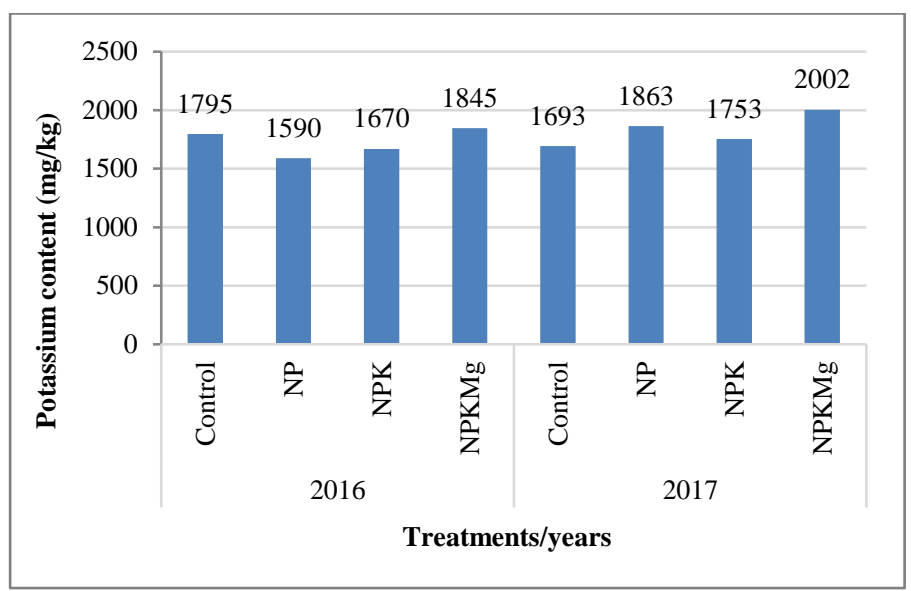

Figure 6. Potassium content of the fruits (Debrecen-Pallag, 2016-2017).

\section{Conclusions}

According to the preliminary data, applied fertilizers resulted in visible differences after only two years. All treatments (NP, $\mathrm{NPK}, \mathrm{NPKMg}$ ) improved the vegetative performance of the sweet cherry trees. Harvested yield, fruit quality and element content of the fruits were also influenced by the fertilizers compared to the control. Evaluating the effects of the single treatments needs further observations in the next years.

\section{Acknowledgements}

This research was financed by the Thematic Excellence Programme of the Ministry for Innovation and Technology in Hungary (ED_18-1-2019-0028), within the framework of the climate change thematic programme of the University of 
Debrecen. The study was also supported by the grant of OTKA K 131478 and by the EFOP-3.6.1-16-2016-00022 project. The project is co-financed by the European Union and the European Social Fund. This work was partly financed by the European Union and the State of Hungary, co-financed by the European Social Fund in the framework of TÁMOP-4.2.4.A/ 2-11/1-20120001 'National Excellence Program' under the project No. A2SZJ-TOK-13-0061.

\section{References}

Balmer, M., Blanke, M. M. (2005): Developments in high density cherries in Germany. Acta Hortic. 667:273-277.

Cantín C. M., Pinochet, J., Gogorcena, Y., Moreno, M. A. (2010): Growth, yield and fruit quality of 'Van' and 'Stark Hardy Giant' sweet cherry cultivars as influenced by grafting on different rootstocks. Sci. Hortic. 123. 329-335. p.

Csihon Á., Bicskei D. K., Dremák P., Gonda I. (2017): Evaluation of the growing and fruit bearing characteristics of the 'Lapins' sweet cherry cultivar grafted on rootstocks with different vigor. International Journal of Horticultural Science 23(1-4): 15-18. https://doi.org/10.31421/IJHS/23/1-4./1195

Csihon, Á., Bicskei, D. K., Dremák, P., Gonda, I. (2018): Performance of sweet cherry cultivars grafted on Colt rootstock. International Journal of Horticultural Science 24(1-2): 7-10. https://doi.org/10.31421/IJHS/24/1-2./1540

FAO (2020): http://www.fao.org/faostat/en/\#data/QC

Gonda, I. (2008): Intenzív gyümölcsösök környezetkímélő tápanyag-gazdálkodása. Debreceni Egyetem AMTC Kertészettudományi és Növényi Biotechnológiai Tanszék, Kutatási és Fejlesztési Intézet. 117.
Matthew, D. W., Lang, G., Ophardt, D. (2005): Rootstock and training system affect sweet cherry growth, yield and fruit quality. HortScience 40(3): 582-586. p.

Nagy, P. T. (2009): Gyümölcsösök tápanyag-gazdálkodásának időszerü kérdései. Debreceni Egyetem, Agrár-és Müszaki Tudományok Centruma, Kutatási és Fejlesztési Intézet. 248. p.

Neilsen, G. H., Neislen, D., Forge, T. (2017): Environmental limiting factors for cherry production. In: Cherries. Botany, production and uses. Eds. Garcia, J. Q., Iezzoni, A., Pulawska, J., Lang, G. CAB International, Boston. 189-222. p.

Papp, J. (2003): Tápanyagellátás. In. Gyümölcstermesztési alapismeretek. Szerk.: PAPP, J. Mezőgazda Kiadó. Budapest. 329-353. p.

Predieri, S., Dris, R., Sekse, L., Rapparini, F. (2003): Influence of environmental factors and orchard management on yield and quality of sweet cherry. Food, Agriculture \& Environment 1(2): 263-266. p.

Quinlan, J. D., Preston, A. P. (1971): The influence of shoot competition on fruit retemontion and cropping of apple trees. Journal of Horticultural Science. 46: 525-534. p.

Sadowski, A., Lenz, F., Engel, G., Kepka, M. (1995): Effect of fruit load on leaf mineral content of apple trees. Acta Horticulturae. 383: 67-71. p.

Vaszily, B., Gonda, I. (2010): Training and maintaining spindle crowns in cherry production. International Journal of Horticultural Science 16(3): 51-53. https://doi.org/10.31421/IJHS/16/3/896

Wilkinson, B. G. (1968): Mineral composition of apple IX. Uptake of calcium by fruit. Journal of Science. Food and Agriculture. 19:646-647. 